\title{
AN EMPLOYEE ENGAGEMENT FRAMEWORK FOR TECHNICAL VOCATIONAL EDUCATION AND TRAINING COLLEGES IN SOUTH AFRICA
}

\author{
M. Mmako \\ Department Management and Entrepreneurship \\ Tshwane University of Technology Polokwane Campus \\ Polokwane, South Africa \\ e-mail: mmakomm@tut.ac.za \\ C. Schultz \\ Department People Management and Development \\ Tshwane University of Technology Pretoria Campus \\ Pretoria, South Africa \\ e-mail: schultzcm@tut.ac.za
}

\section{ABSTRACT}

Employee engagement refers to what takes place when people are interested in a positive way and when they are excited about their jobs, exercise discretionary behaviour and are motivated to achieve high levels of performance. The present research therefore examined employee engagement of the academic staff in the Technical Vocational Education and Training (TVET) Colleges in South Africa. A quantitative design was used. In total, 2054 academic staff completed the questionnaire. A self-administered 4-point Likert-type scale questionnaire was developed. The data was gathered and then analysed by using the Statistical Packages for the Social Sciences (SPSS). Descriptive statistics were used to present the findings. An employee engagement framework, which incorporates the main ideas of the article, suggests a new perspective about how to foster and manage employee engagement in today's workplace is presented.

Keywords: employee engagement, academic staff, higher education institutions, Technical Vocational Education and Training Colleges, South Africa

\section{INTRODUCTION}

Higher education institutions (HEIs) worldwide are developing a disturbing imbalance with their environment (Mxenge, Dywill and Basaza 2014, 129). This is due to the fact that HEIs face an overload of demands but are somewhat under-equipped with response mechanisms or strategies (Barkhuizen and Rothman 2008, 321). This overload of demands with minimal response mechanisms often leads to high levels of stress among the employees of the institutions, often giving rise to employees leaving the institution or showing signs of wanting 
to leave the institution (Mxenge et al. 2014, 129). The South African Technical Vocational Education and Training (TVET) sector faces major challenges to produce, recruit and retain all categories of academic and teaching professionals. According to Maharaswa (2013, 8), the TVET Colleges had a minimum demand for 400000 students and about 660000 students in 2012. In 2013, the TVET Colleges had a total student enrolment of approximately 640000 students and a staff complement of more than 10000 lecturers (DHET 2013). The large percentage of students who enrol in TVET Colleges leads to bigger work-load for the academics. Academics at TVETs find it difficult to cope with the increased number of students and demands for academic support (National Planning Commission 2011).

The afore-mentioned developments present major challenges for academic staff. Academic staff has to perform complex tasks within an increasing demanding environment (Houston, Meyer and Paweai 2006, 18). Performing these tasks without necessary job resources leads to stress (Daly and Dee 2006, 778; Gillespie et al. 2001, 56; Kinman and Jones 2003, 24) which might result in low organisational commitment (Barkhuizen, Rothman and Van de Viljver 2013, 324; Kinman 2001, 47).

Another challenge is the lecturer student ratio. According to the Synthesis Report of the TVET Colleges Technical Task Team (2014), there are gaps in the capabilities of lecturers given the competence required for effective lecturing as well as coping with large classes and classes for remedial teaching and for teaching mixed ability classes, and they should be competent in both the theoretical and practical aspects of the courses that they teach (DHET 2013).

In addition, the TVET Colleges had the challenge of facilitating and maintaining positive learning experiences for students, thereby effectively doubling the need for qualified academics. One of such problem is that there is a lack of capacity in academic development amongst the lecturers. These issues were again picked up in the White Paper for Post-School Education and (DHET 2014). These have resulted in a series of negative effects such as a loss of motivation and lack of employee engagement.

Although a plethora of research, which dealt predominantly with advanced employee engagement (Bakker and Demerouti 2008, 212; Bakker and Demerouti 2009, 222; Bakker, Albrecht and Leiter 2011, 5; Schaufeli, Bakker and Salanova 2006, 702) has investigated the issue of employee engagement, the amount of empirical research investigating the issue of engagement at TVET Colleges of South Africa is limited. Unfortunately, much of what has been written about employee engagement comes from the practitioner literature and consultation firms (Saks 2006, 600). Cawe (2006, 306), Gill (2012, 46), Mani and Nadu (2011, 
17), Rothman and Rothman $(2010,1)$ as well as Taipale et al. $(2011,488)$ note that some of the studies have focused on antecedents and consequences of work engagement. These studies however, are not specific to the TVET sector. It is interesting that, despite this widespread interest in employee engagement, there is actually very little research on engagement of academic staff at TVET Colleges (Toews and Yazadjian 2007, 113). Results of the research are considered to reflect challenges that need to be resolved. The core purpose of the present study was to identify the factors affecting engagement of academic staff at TVET Colleges. The present investigation sought to contribute to the retention of academic staff in the TVET environment in South Africa by making recommendations for developing an employee engagement framework based on the findings of the study.

The research problem was addressed by identifying factors affecting academic staff employed in the TVET colleges. The purpose of the present study was to gain knowledge of the factors affecting the academics in order to make recommendations for human resource management practitioners and employee engagement practices. In addition, the findings will also permit future studies to further explore the value of information generated by this study further.

\section{Employee engagement}

Employee engagement has spawned a great deal of interest and activity since its inception in the organisational behaviour literature (Kahn 1990, 691). Albrecht $(2010,841)$ posits that employee engagement remains a 'hot topic' in the academic and practitioner domains, and indicates, 'an employee's cognitive, emotional, and behavioral states are directed toward organisational outcomes'. These states assist engaged employees in the workplace to perform activities according to the mandatory requirements.

A number of differences are prevalent in the sample of definitions below. Various experts focus on different aspects of the subject. Some place the focus on what drives engagement, while others look at the effects of employee engagement. Some definitions emphasise the role played by top management, while other definitions consider the state of engagement and how it feels to be engaged (Holbeche and Matthews 2010, 10). Employee engagement is inter alia the following:

- 'a positive attitude an employee holds towards the organisation and its value' (Ariani 2013, 46);

- 'the individual's involvement and satisfaction with as well as enthusiasm for work' (Shuck 
and Wollard 2010, 97);

- 'the state of emotional and intellectual involvement which motivates employees to do their best work’ (Habraken 2013,12); and

- 'what takes place when people are interested in a positive manner and excited about their jobs, exercise discretionary behaviour and are motivated to achieve high levels of performance’ (Armstrong 2012, 168).

It is evident from this sample of employee engagement definitions, that engagement involves a relationship between the organisation and an employee.

\section{PROBLEM STATEMENT}

Since their inception in 2006 TVET Colleges have been under control of the Provincial Member of the Executive Council (MEC) and managed by the Provincial Department of Education (PDE). The implementation of the college policy was introduced unevenly across provinces and there is very little uniformity (Papier, Needham and McBride 2012, 5). College staff insecurities and the uneven introduction policy resulted in persistent representation to the newly formed Department of Higher Education and Training (DHET) to return college staff to state employment, and the transfer of former state staff establishment back from college councils. This staffing issue has resulted in colleges losing qualified officials and lecturers. Another challenge lies with the high numbers of students and large lecturer student ratios resulting from the reinstatement of the National Technical Education (NATED) programmes (Report 191) in 2009. This move introduced another challenge for colleges, which have to cope with the workload from both the National Certificate Vocational (NCV) and NATED programmes (DHET 2012).

\section{PURPOSE OF THE STUDY}

The purpose of the present study was to determine the factors related to employee engagement of academic staff at TVET Colleges and thereafter to develop an employee engagement framework for TVET Colleges in South Africa.

\section{RESEARCH DESIGN}

A survey design was used in this study. A quantitative research approach was followed. Quantitative research is a formal, objective, systematic process during which numerical data are used to obtain information about the world (Burns and Groove 2009, 22). The quantitative 
research objective is to make observations more explicit and to make aggregating and summarising data easier (Babbie 2005, 25). A quantitative research design was used in the present study with a descriptive orientation. According to White (2009, 62), descriptive research is a "non-experimental quantitative research method that is concerned with conditions or relationships that exist, practices that prevail, or attitudes that are held'. In the context of this study, respondents' perceptions about challenges, expectations and personal views regarding employee engagement within their TVET colleges were explored deductively and described and the results presented here in frequencies.

\section{POPULATION AND SAMPLE}

Population refers to a targeted group, whereas a sample refers to population microcosms (Ormrod and Leedy 2010, 205). For the present study, the target population was the academic staff members from the 18 TVET institutions in South Africa. Non-probability sampling was followed to select a sample of approximately 3000 academic staff. Large and small TVET colleges within each province were selected. A total of 3000 questionnaires were handed out and 2054 (68.3\%) were fully completed and returned and, were considered for analysis.

\section{Method of data collection}

Data collection was undertaken by using a self-administered data-collection instrument in February 2014. This type of questionnaire was decided upon to be the best method of obtaining the required information to address the problem in that it is low in cost in terms of both time and money and inflow of data is quick and from many people. The questionnaire comprised two sections. Section A consisted of the respondents' biographic and demographic information. Section B comprised five factors and sub-factors extracted from the literature review with 24 items to be rated on a 4-point Likert-type scale: (1) = Strongly agree, $(2)=$ Agree, $(3)=$ Disagree, and (4) = Strongly disagree. According to Burns and Grove (2009, 707), a Likerttype scale is an instrument designed to determine respondents' opinions or attitudes, and contains a number of declarative statements about the topic with a selection scale after each statement. A closed-ended question allowed respondents to make fine distinctions between attitudes, and to maintain consistency in their ratings more easily. The respondents completed the questionnaires and returned them in a sealed envelope on an arranged date. The instrument took around 20 minutes to complete. The questionnaires were accompanied by small research boxes for the respondents to put their completed questionnaires into. The advantage of this sealed envelope was that it protected the anonymity of the respondents. 


\section{Data analysis}

The Statistical Package for the Social Sciences (SPPS) software program was used to analyse the data. Inferential statistics were used to make judgments about the probability that an observed difference between groups was a dependable one (Neuman 2011, 52). The Kaiser Meyer Olkin measure of adequacy (KMO) was used to determine whether the sample size was sufficient to continue with a factor (Hair et al. 1998, 89). The KMO measure of sampling adequacy was 0.934 . According to Kaiser $(1970,409)$ 'the KMO should be 0.60 or higher in order to proceed with factor analysis'. Kaiser $(1970,409)$ suggests a cut-off value of 0.5 and a desirable value of 0.8 or higher. Bartlett's test of sphericity with 0.000 probability value was significant $(\mathrm{p}<0.05)$, which also indicates sampling adequacy. A principal axis factor analysis with a direct oblimin rotation was performed on the 25 items to investigate the grouping of items and their correspondence to the original theoretical scales. One of the major applications of factor analysis is to summarise the data to be more manageable without losing any of the important information, therefore making it easier to test theories (Cooper and Schindler 2011, 545; Huck 2012, 482).

The initial stage of research in the noted domains was driven by the need to determine the number of meaningful factors. For this purpose, five factors were selected and 25 items used. Before factor analysis was performed, the theoretical investigation identified five factors from the theoretical investigation, which were as follows: namely, organisational culture, organisational strategy, leadership, performance management and discretionary effort. Through the factor analysis process, the study arrived at four meaningful scales as namely, recognition and feedback, attitude towards direct manager, commitment to institution and socialisation and values.

\section{Reliability and validity}

According to Adler and Clark (2011, 147), reliability refers to the degree to which a measure yields consistent results, while validity refers to the capacity of research techniques to encapsulate the characteristics of the concepts being studied, and so to measure what the methods were intended to measure properly (Gray 2009, 157). Item analysis was calculated and the Cronbach's alpha for the total scale by eliminating each item individually, where the contribution of each item can be determined. The analysis of items in each of the factors emerged from the factor analysis. The recognition and feedback factor had an acceptable Cronbach's alpha score of 0.817 , the attitude towards direct manager factor had a Cronbach's 
alpha coefficient of 0.850 , where all the individual items contributed well to total reliability. The commitment to institution factor had a Cronbach's alpha of 0.766 , socialisation and values factor had a Cronbach's alpha of 0.819 which was above the accepted value of 0.70 (Anastasi and Urbina 1997, 145). The factors were deemed appropriate since each of them exhibited a result above the 0.05 Cronbach's alpha coefficient point. This allowed the researcher to conclude that the internal level of consistency of the measurement instrument was acceptable for these items. The item total correlations indicated a statistically sound internal consistency.

In ensuring face validity, a pre-research pilot study was conducted to determine whether potential respondents would have difficulties in understanding or interpreting questions in the questionnaire. Face validity of the questionnaire in this study was used. There was consensus that the questionnaire appeared to measure what it claimed to measure. Content validity refers to how well reflect the construct being measured (Burns and Grove 2009, 380) and this was ensured by the development of the statements in the questionnaire based on the literature review on employee engagement.

\section{Research ethics}

The researcher exercised care that the rights of individuals and institutions were safeguarded by deliberately excluding any request for identifying personal details within the construct of the questionnaire (Marshall and Rossman 2011, 46). The researcher included the purpose of the research study in the research invitation and discussed the purpose with procedures on the consent form (Neuman 2011, 149).

Each respondent voluntarily signed a consent form that was folded and placed in a research box prior to completion of the questionnaire. Each completed questionnaire was then placed in a separate envelope. The respondents were assured that the information would only be made available to the researcher, supervisor and statistician, and would be treated with confidentiality. No signed consent form could be linked to any specific questionnaire. The respondents were informed that their participation in the proposed study was voluntary and they had the right to withdraw from the study at any time and without any penalty (Burns and Grove 2009, 190).

\section{FINDINGS}




\section{Respondents' biographic and demographic data}

In terms of biographical data, the respondents ranged from 20 to 69 years, with a mean age of 42.29 and a standard deviation of 10.85. This information indicates that the majority of respondents were between the ages of 31 and 51 years. Regarding gender, the respondents were predominately males (63.4\%), while females comprised 36.6 per cent of the total number of respondents. In terms of the province distribution from the 2054 questionnaires received 18.4 per cent were from Gauteng, 14.4 per cent from KwaZulu-Natal, 13.7 per cent from the Eastern Cape, 13.1 per cent from Limpopo, 12.8 per cent from the Free State, 9.8 per cent from the Western Cape, 8.3 per cent from Mpumalanga, 5.0 per cent from the Northern Cape, and 4.5 per cent from North West. The majority of the respondents therefore represented the provinces of Gauteng and KwaZulu-Natal, South Africa. The majority of respondents were lecturers (53.7\%), the second largest group comprised senior lecturers (19.7\%), followed by education specialists (19.4\%), while the lowest numbers were deputy chief education specialists (4\%). The participants were employed at a number of different departments. The majority of respondents were employed at engineering studies (40.5\%), followed by general studies (37.4\%), while business studies (19.0\%) had the lowest number of respondents. Regarding years of service, the majority of academics (26.7\%) had more than five years of service but less than 10 years and 19.6 per cent between 10 and 15 years of service. A further 17.3 per cent of respondents had less than five years of service. Some 13.7 per cent of respondents had less than two years of service with the organisation. As the years of service increased, for example, 20 years (12.9\%), 25 years (6.9\%), and 30 years (2.5\%), the number of respondents decreased. Only 2 per cent of the respondents had more than 30 years of service with the organisation. The respondents mostly had a four-year degree qualification (44.48\%), the second-most number of respondents (31.12\%) had an honours degree, followed by (19.21\%) with a three-year diploma qualification. The lowest percentage (5.18\%) had a master's qualification. It can be concluded that on average the target group was a qualified group of academics.

The four-factor analysis of the statements in Section B of the questionnaire is shown in Table 1.

Table 1: Four-factor analysis results of the principal axis factor analysis 


\begin{tabular}{|c|c|c|c|c|}
\hline \multirow[b]{2}{*}{ Statement is the questionnaire } & \multicolumn{4}{|c|}{ Factor } \\
\hline & 1 & 2 & 3 & 4 \\
\hline $\begin{array}{l}\text { I am hopeful for my long-term career opportunities in my } \\
\text { institution. }\end{array}$ & .609 & & & \\
\hline $\begin{array}{l}\text { I have received recognition for my accomplishments, } \\
\text { which enhances my commitment to do the job. }\end{array}$ & .592 & & & \\
\hline $\begin{array}{l}\text { I receive constructive feedback to improve my job } \\
\text { performance. }\end{array}$ & .500 & & & \\
\hline I am satisfied with my job. & .477 & & & \\
\hline $\begin{array}{l}\text { Training offered in this institution enables me to extend } \\
\text { my professional development. }\end{array}$ & .432 & & & \\
\hline $\begin{array}{l}\text { I plan to continue my career with this institution for at } \\
\text { least two more years. }\end{array}$ & .381 & & & -.228 \\
\hline I am allowed to perform my tasks independently. & .295 & & & \\
\hline $\begin{array}{l}\text { The way in which my performance is evaluated is } \\
\text { effective. }\end{array}$ & .270 & & & -.232 \\
\hline $\begin{array}{l}\text { My direct manager creates an atmosphere of mutual } \\
\text { trust. }\end{array}$ & & -.862 & & \\
\hline My direct manager motivates me to work at my best. & & -.808 & & \\
\hline $\begin{array}{l}\text { My direct manager pays attention to my job-related } \\
\text { needs. }\end{array}$ & & -.701 & & \\
\hline My direct manager supports me in doing my job well. & & -.566 & & \\
\hline $\begin{array}{l}\text { My direct manager inspires me to exchange work-related } \\
\text { knowledge with my colleagues. }\end{array}$ & & -.507 & & \\
\hline $\begin{array}{l}\text { I am committed to the mission statement of this } \\
\text { institution. }\end{array}$ & & & .842 & \\
\hline $\begin{array}{l}\text { I understand how my work directly contributes to the } \\
\text { overall vision of the institution. }\end{array}$ & & & .626 & \\
\hline $\begin{array}{l}\text { The achievement of my goals is aligned with the goals of } \\
\text { this institution. }\end{array}$ & & & .543 & \\
\hline I am more committed to perform to the best of my ability. & .224 & & .410 & \\
\hline I contribute significantly towards institutional objectives. & & & .274 & \\
\hline I am proud of this institution's identity. & .202 & & .273 & -.233 \\
\hline $\begin{array}{l}\text { This institution provides its employees with socialisation } \\
\text { activities to adjust to a new organisational setting. }\end{array}$ & & & & -.778 \\
\hline $\begin{array}{l}\text { This institution has a clear set of values underpinning } \\
\text { continuous employee involvement. }\end{array}$ & & & & -.738 \\
\hline $\begin{array}{l}\text { In this institution mentoring programmes assist me to be } \\
\text { more effective in my job. }\end{array}$ & & & & -.615 \\
\hline $\begin{array}{l}\text { I voluntarily do more than the job requires so that I } \\
\text { contribute to the efficient operation of the institution. }\end{array}$ & & & .298 & -.367 \\
\hline The image of this institution is positive. & .249 & & .230 & -.273 \\
\hline My institution supports me to perform my duties. & & & & -.269 \\
\hline
\end{tabular}

From Table 1 the following four factors were derived:

Factor 1: Socialisation and values

Factor 2: Recognition and feedback

Factor 3: Attitude towards direct manager

Factor 4: Commitment to the institution

The Cronbach's alpha values for the four factors resulted from the factorial structure suggested that the questionnaire was a reliable measuring instrument (see Table 2). 
Table 2: Cronbach's alpha values for the four factors

\begin{tabular}{|l|l|}
\hline Cronbach's alpha for the four factors & Cronbach alpha if items are deleted \\
\hline Recognition and feedback factor & 0.817 \\
\hline Attitude towards direct manager factor & 0.850 \\
\hline Commitment to the institution factor & 0.766 \\
\hline Socialisation and values factor & 0.819 \\
\hline
\end{tabular}

The recognition and feedback factor had an acceptable Cronbach's alpha score of 0.817 , the attitude towards direct manager had a Cronbach's alpha coefficient of 0.850 , where all the individual items contributed well to total reliability. The commitment to the institution factor had a Cronbach's alpha of 0.766, socialisation and values factor had a Cronbach's alpha of 0.819 which was above the accepted value of 0.70 (Anastasi and Urbina 1997, 145). The factors were deemed appropriate since each of them exhibited a result above the 0.05 Cronbach's alpha coefficient point. This allowed the researcher to conclude that the internal level of consistency of the measurement instrument was acceptable for these items. The item total correlations indicated a statistically sound internal consistency.

\section{DISCUSSION}

The four factors and the employee engagement framework are discussed below:

\section{Factor 1: Socialisation and values}

The academics at TVETs in general strongly disagreed with the socialisation and values factor. This indicates that they were strongly disengaged with the organisation's identity, image, mentoring programs, voluntarily doing job and socialisation activities.

A number of studies have regarded values and work values in particular as a significant variable in describing organisational commitment (Conway and Briner 2002, 282). For individual employees, work commitment signifies a positive relationship with the organisation (Lee and Chen 2013, 199). The supervisors and HR personnel need to explain the culture of the organisation, while employees need to highlight their own work values in order to create a mutual understanding of the initial value fit between the employees and the TVET College sector. Colleges could consider arranging comprehensive socialisation activities for their employees to facilitate learning about various aspects of the colleges' environment. For effective organisation socialisation, managers need to implement socialisation programs that would increase the employee interaction and cooperation (Lee 2012, 1053). Govender (2011, 175) states that the process would include inter alia, formal training programs that teach employees the technical skills associated with performing their jobs, and daily interactions with 
employees and managers. Bhatnagar (2007 in Agarwal, Datta, Blake-Beard and Bhargava 2012, 7) mentions that mentoring activities enhance employee engagement, stimulate personal development, and increase work engagement among employees. Mentoring programs would help the mentees to develop their teamwork, collaboration, and innovation, and to help develop up-and-comers faster more effectively, while mentors learn new perspectives from their mentees (Liebowitz 2010, 54).

One can safely assert that by providing activities, such as mentoring, face-to-face interaction, inviting new employees to talk about their work preferences, job goals and career aspirations, and creating a culture that fits employees' values and implementing socialisation programs and practices, the TVETs promote employee engagement.

\section{Factor 2: Recognition and feedback}

The reliability analysis showed high reliabilities for the overall recognition and feedback factor and its items. It can therefore be concluded that the recognition and feedback factor is a valid and reliable measure and may be included in the employee engagement framework.

Recognition and feedback items were cross-referenced at other points in this study. Thus, being unhappy about recognition and feedback in the institution was identified as the most likely reason why academics in the sample would consider leaving their institution and plan not to continue with their career in the institution for at least two more years. The results suggest that the academics did not perceive recognition and feedback they received to be adequate. The same results are reported by Ngobeni and Bezuidenhout $(2011,9966)$ who, for example report that inadequate employee recognition was linked to lower employee engagement and higher turnover intentions in a South African Higher Education Institution (HEI). Research conducted by Dobbelaer, Prins, and Van Dongen $(2013,89)$, posits that positive feedback adds to the recipient's motivation to achieve the desired results. Other such connections have been made by Krasman $(2012,1)$, namely that the feedback environment is a proximal variable in the performance management process. Academic staff members have a severe need for recognition and feedback, both in a professional and social capacity, which means that the TVET College sector is challenged in the sense that academic staff need a sense of belonging and pride in their jobs. Employees respond to appreciation expressed through recognition of their good work because recognition confirms that their work is valued. James et al. (1978) in Lee (2012, 785) a study revealed that employees are more likely to be more motivated to invest themselves in their work when they believe that their job is recognised and supported by the organisation. TVET College sector managers should value employees' work and motivate them to maintain 
and improve their good work.

Direct performance feedback for employees should be provided. Employees prefer feedback regarding their strengths and weaknesses and what is expected from them to understand their career prospects (Risher 2012, 188). When managers keep employees informed such employees tend to feel a greater sense of worth. Senior management has to support this process, while line managers are part of daily performance management as a specific strategy to engage employees (Risher 2013, 65). Mone and London (2010, 227) support the fact that performance management effectively applied will help to create and sustain high levels of employee engagement, which leads to higher levels of performance. As suggested by Komati and Zhou (2013, 3), managers need to set goals appropriately, deliver constructive ongoing feedback, and assess the right competence to evaluate performance. Establishing an effective performance appraisal process can improve employee performance, which in turn would improve organisational performance (Liu and Dong 2012, 155). Employee performance can be achieved through promoting employee engagement. This is supported by Bakker and Demerouti $(2008,212)$ and Saks $(2006,607)$ who predicted and found a significant relationship between employee performance and employee engagement.

Managers should demonstrate to employees how employees' feedback is being used, for example by holding regular one-on-one meetings with employees and showing genuine care and concern for them, following-up on issues on behalf of employees, and giving positive, constructive and specific feedback to them.

\section{Attitude towards direct manager}

The reliability analysis showed high reliabilities for the overall attitude towards direct manager factor and its items. It can therefore be concluded that this factor is a valid and reliable measure, and may be included in the employee engagement framework.

Regarding attitude towards the direct manager, the results, on average, show that the respondents disagreed that the direct line management support they receive is adequate. From this finding, it can be deduced that direct line managers in TVETs are inadequate in managing their academics. This study indicates a positive relationship between recognition and feedback and attitude towards the direct manager. This study clearly suggests that recognition and feedback on employees and attitude towards direct manager may be in the best interest of the employer. A Gallup study demonstrates that giving feedback on surveys relates to improvement in upward feedback scores (direct report to managers) (Harter, Schimidt and Keyes 2001, 4). Gallup's organisational work, have further found the importance of the supervisor in the 
feedback process to be critical.

As a matter of urgency, the TVET Colleges should promote a positive attitude in their employees towards their direct managers. This would enhance employee engagement focusing on managers leading by example, which generates enthusiasm and inspires employees to work harder, and to create a positive relationship with a manager who cares. An employee also wants to feel that the direct manager is interested in him or her as a person and cares about his or her life. One way to achieve this would be to create an atmosphere of mutual trust and to support employees in doing their jobs well. Another option would be to enable employees to establish the most direct relationship possible with immediate managers. Another possibility to create a positive attitude would be to focus on employees' job-related needs, and inspire them to exchange work-related knowledge with their colleagues.

Managers need to have an influence on their followers' engagement with good and sound management practices, which at the same time encourage followers to develop ideas, take initiatives and contribute input to their organisation (Papalexandris and Galanaki 2009, 131).

\section{Factor 4: Commitment to the institution}

Regarding the assessment of commitment to the institution for academic staff, the majority of the participants agreed with most of the statements in this factor. Literature has shown that clearly defined goals, vision, mission, organisational image and organisational identity have a significant influence on the engagement levels of employees. Some of the respondents did not seem to have a problem with the vision, mission, and goals of the organisation per se, because they agreed that they were committed to the vision and mission of the organisation. Some of these respondents indicated that they do contribute significantly towards institutional objectives. Previous research proved that there is a positive relationship between employee engagement and affective commitment (Albdour and Altarawneh 2014, 209; Hakanen, Bakker and Schaufeli 2006, 500; Maslach, Schaufeli and Leiter 2001, 400). Another correlation between employee engagement and organisational commitment was addressed by Saks (2006, 607), Sanalova et al. (2003, 45) and Schaufeli and Bakker (2004, 297). The finding is also consistent with results from a study by Agyemang and Ofei $(2013,29)$. Based on this body of work, newcomers who are more socialised should be more committed than their less-socialised peers. This is because socialisation involves giving employees information through structured experiences, which can help them overcome their anxiety, confusion and concern about their roles, which in turn can increase their attachment to and identification with the organisation (Cohen and Veled-Hecht 2010, 395). 
The main objective of the research was to identify the factors that could affect the employee engagement of academic staff and develop an employee engagement framework for the TVET Colleges in South Africa. This employee engagement framework was developed by integrating the factors of the factor analysis and the literature review.

Figure 1 depicts an employee engagement framework that illustrates the relationship between the different factors of employee engagement for academic staff. The underpinning framework would provide structure to TVET Colleges and HR practitioners to communicate how employee engagement can be achieved, and importantly, how employee engagement influences the important institutional performance indicators such as high employee morale, low employee turnover, and low absenteeism as well as retention. The framework details the key elements of employee engagement which could contribute to the delivery of the organisation's priorities, by promoting, building confidence in and support, its vision and activities among its employees.

The proposed employee engagement framework comprises four factors. Building upon the employee engagement literature, the framework suggests the process of employee engagement should be an interlinked, continuing process that consists of several elements, but in particular the following, interrelated elements:

- recognition and feedback: training and development programmes, transfer of skills, regular reviews and feedback sessions, knowledge sharing;

- $\quad$ attitude towards direct manager: management support, trustworthiness, transparency and open communication, working relationship;

- commitment to the institution: objectives setting, alignment of employee and organisation goals, strategy and mission, positive and supportive corporate culture; and

- $\quad$ socialisation and values: mentoring programmes, defined values/codes, empowering and motivating staff, and involving authentically. 

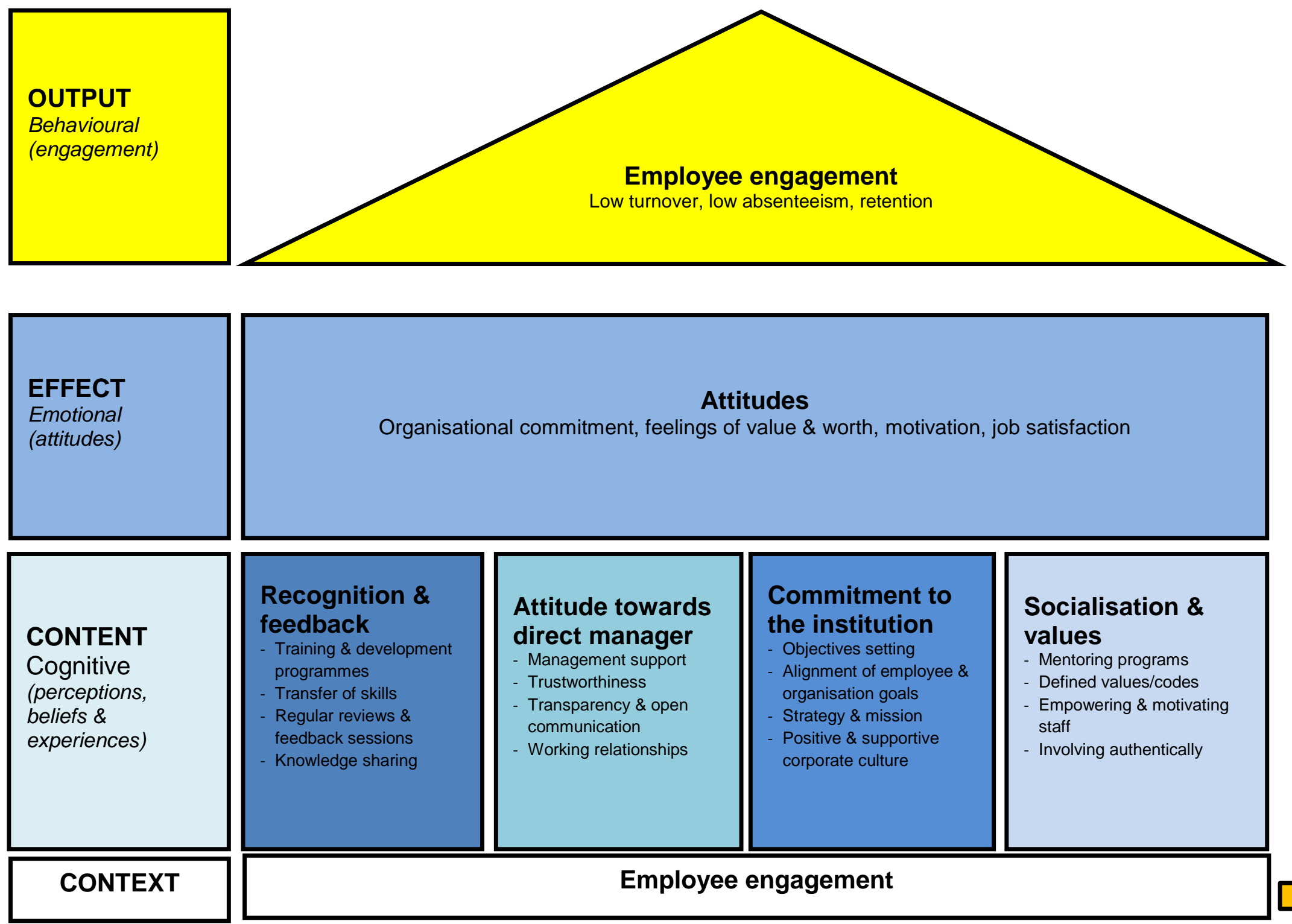



Figure 1: Employee engagement framework 
Cognitive engagement defines employees' beliefs, perceptions and experiences about the organisation, management and working conditions (Sakovska 2012, 6). This implies that employees are sure about their job requirements and role expectations, whether their work is meaningful and safe (physically, emotionally and psychologically) and whether employees have sufficient levels of resources to complete their work (Shuck and Reio 2014, 46). This further means that the work environment is used to determine the overall significance of a situation and serves as the catalyst towards the intention to engage. Emotional engagement defines employees' positive attitude, how they feel about their employer, organisational values, leaders and working conditions (Jose and Mampilly 2012, 95). This implies that employees receive constructive feedback and have social interactions with their co-workers, which connect them to other members of the organisation. When employees are emotionally engaged with their work, they invest personal resources of pride, commitment, feelings of value and work, as well as motivation). Behavioural engagement relates to being willing to 'go the extra mile' for one's employer. It also refers to physical manifestation of the cognitive and emotional engagement combination (Van Schalkwyk et al. 2010, 2).

The Employee Engagement Framework adds value since it can be applied as a frame of reference in understanding the complexities of engagement for academic staff. It also has a wider applicability. While it has been developed in a TVET context, the framework can be applied to any other institution of higher education, which has a need to build the capacity of academic staff.

\section{DIRECTIONS FOR FUTURE RESEARCH}

Several clear areas for future research emerged from this research, namely measuring the extent of the engagement of employees in different institutional layers and determining whether different employee engagement dimensions can be applied in each layer or not; investigating the consistency of the relationship between recognition and feedback; attitudes towards direct manager; commitment to the institution, socialisation and values; and adding more employee engagement variables to the framework.

Another area for further research would be to conduct similar research focused specifically on the individual and organisational factors that influence and promote employee engagement at TVET Colleges.

Future research using a cross-sectional research design is called for which implies that the dependent variable (employee engagement) and the independent variables (factors under study) are 
measured at the same time.

\section{CONCLUSION}

In conclusion, this study indicated that the employee engagement framework for TVET Colleges provides a meaningful theoretical basis for understanding and studying employee engagement. Hence, implementing this framework is critical to reducing employee turnover and improving employee engagement.

In this research, employee engagement literature led to the researcher concluding that most of the executives and managerial employees try to recognise and implement strategies that help to increase employee engagement, but to make effective implementation of the framework, the message to management should be that they should be vigilant about ensuring that employees are engaged. Moreover, every factor in the framework should be given enough time to work on it in order to achieve the ultimate goal of employee engagement.

The results of the present study extended previous research findings by pointing toward comprehensive understanding of how employee engagement factors inter-relate to influence discretionary effort and turnover intentions in the TVET sector context. The results show that recognition and feedback, attitudes towards the direct manager, commitment to the institution, and socialisation and values can successfully develop a framework.

\section{REFERENCES}

Adler, E. S. and R. Clark. 2011. An invitation to social research: How it's done. 4th ed. Belmont: Wadsworth.

Agarwal, U. A., S. Datta, S. Blake-Beard and S. Bhargava. 2012. Linking LMX, innovative work behavior and turnover intentions: The mediating role of work engagement. Career Development International 17(3): 208-230.

Agyemang, C. B. and S. B. Ofei. 2013. Employee work engagement and organizational commitment: A comparative study in private and public sector organization in Ghana. European Journal of Business and Innovation Research 1(4): 20-33.

Albdour, A. A. and I. I. Altarawneh. 2014. Employee engagement and orgnizational commitment: Evidence from Jordan. International Journal of Business 19(2): 198-212.

Albrecht, S. L. 2010. The influence of job, team and organizational level resources on employee well-being, engagement, commitment and extra-role performance: Test of a model. International Journal of Manpower 33(7): 840-853.

Anastasi, A. and S. Urbina. 1997. Psychological testing. Upper Saddle River, NJ: Prentice-Hall.

Ariani, D. W. 2013. The relationship between employee engagement, organizational citizenship behavior, and counterproductive work behavior. International Journal of Business Administration 4(2): 46-56.

Armstrong, M. 2012. Armstrong's handbook of human resource management practice. 12th ed. London: 
Graphicraft.

Babbie, E. 2005. The basics of social research. 3rd ed. Belmont, CA: Thomson Wadsworth.

Bakker, A. B. and E. Demerouti. 2008. Towards a model of work engagement. Career Development International 13(3): 209-223.

Bakker, A. B. and E. Demerouti. 2009. The crossover look at the role and empathy. Journal of Managerial Psychology 24(3): 220-236.

Bakker, A. B., S. Albrecht and M. P. Leiter. 2011. Key questions regarding work engagement. European Journal of Work and Organizational Psychology 20(1): 4-28.

Barkhuizen, N. and S. Rothman. 2008. Occupational Stress of academic staff in South African higher education institutions. South African Journal of Psychology 28(2): 321-336.

Barkhuizen, N., S. Rothman and F. J. R. van de Viljver. 2013. Burnout and engagement of academics in higher education institutions: Effects of dispositional optimism. Stress Health 30: 322-332.

Burns, N. and S. K. Groove. 2009. The practice of nursing research: appraisal, synthesis, and generation of evidence. 6th ed. Saunders Elsevier, St. Louis Missouri.

Cawe, M. 2006. Factors contributing to employee engagement in South Africa, Master's thesis. University of the Witwatersrand, Johannesburg.

Cohen, A. and A. Veled-Hecht. 2010. The relationship between organizational socialization and commitment in the workplace among employees in long-term nursing care facilities. Personnel Review 39(5): 537-556.

Conway, N. and R. B. Brine. 2002. A daily diary study of affective responses to psychological contract breach and exceeded promises. Journal of Organizational Behavior 23: 287-302.

Cooper, D. R. and P. S. Schindler. 2011. Business research methods. 11th ed. New York, NY: McGrawHill.

Daly, C. J. and J. R. Dee. 2006. Greener pastures: Faculty turnover intent in urban public universities. The Journal of Higher Education 77(5): 776-803.

Department of Higher Education and Training. 2012. South Africa's Green Paper for post-school education and training. Pretoria: Government Printer.

Department of Higher Education and Training. 2013. Statistics on post-school education and training in South Africa. Pretoria: Government Printer.

Department of Higher Education and Training. 2014. South Africa's White Paper for post-school education and training. Pretoria: Government Printer.

Devlin, A. S. 2006. Research methods: Planning, conducting and presenting research. Belmont, MA: Thomson.

Dobbelaer, M. J., F. J. Prins and D. van Dongen. 2013. The impact of feedback training for inspectors. European Journal of Training and Development 37(1): 86-104.

Gill, P. S. 2012. An investigation of employee engagement and business outcomes at an engineering services firm. PhD thesis. College of Technology. Eastern Michigan University. Ypsilanti, MI.

Gillespie, N. A., M. Walsh, A. H. Winefield, S. J. Dua and C. Stough. 2001. Occupational stress in universities: Staff perceptions of the causes, consequences and moderators of stress. Work and Stress 15(1): 53-72.

Govender, K. 2011. Conceptualising the postgraduate research (service) experience. International Journal of Educational Administration and Policy Studies 3(11): 170-178.

Gray, D. E. 2009. Doing research in the real world. 2nd ed. London: Sage.

Habraken, M. M. P. 2013. Establishing employee engagement within a Dutch hotel. Masters' thesis, 
University of Twente, Enschede.

Hair, J. F., R. E. Anderson, R. L. Tatham and W. C. Black. 1998. Multivariate data analysis with readings. 4th ed. Upper Saddle River, NJ: Prentice-Hall International.

Hakanen, J. J., A. B. Bakker and W. B. Schaufeli. 2006. Burnout and work engagement among teachers. Journal of School Psychology 43(2006): 495-513.

Harter, J. K., F. L. Schimidt and C. L. M. Keyes. 2002. Well-being in the workplace and its relationship to business outcomes: A review of Gallup studies. In C. L. Keyes and J. Haidt. Washington, DC: American Psychological Association.

Holbeche, L. and G. Matthews. 2010. ENGAGED: Unleashing your organization's potential through employee engagement. San Francisco, CA:

Houston, D., L. H. Meyer and S. Paweai. 2006. Academic staff workloads and job satisfaction: Expectations and values in academe. Journal of Higher Education Policy and Management 28(1): 17-30.

Huck, S. W. 2012. Reading statistics and research. 6th ed. Upper Saddle, NJ: Pearson.

Jose, G. and S. R. Mampilly. 2012. Satisfaction with HR practices and employee engagement: A social exchange perspective. Journal of Economics and Behavioural Studies 4(7): 423-430.

Kahn, W. A. 1990. Psychological conditions of personal engagement and disengagement at work. Academy of Management Journal 33(4): 692-724.

Kaiser, H. F. 1970. A second generation little jiffy. Psycometrika 35(4): 401- 415.

Kinman, G. 2001. Pressure points: A review of stressors and strains in UK academics. Educational Psychology 21(4): 474-492.

Kinman, G. and F. Jones. 2003. 'Running up the down escalator': Stressors and strains in UK academics. Quality in Higher Education 9(1): 21-38.

Komati, M. and Y. Zhou. 2013. What are the most efficient and effective practices surrounding performance management. http://digitalcommons.ilr.cornell.edu/cgi?article=1034\&context= student/35/ (accessed 8 October 2015).

Krasman, J. 2012. The feedback-seeking personality: Big five and feedback seeking behavior. Journal of Leadership and Organizational Studies 17(1): 18-32.

Lee, C. and C. Chen. 2013. The relationship between employee commitment and job attitude and its effect on service quality in the tourism industry. American Journal of Industrial and Business Management 3(3): 196-208.

Lee, J. 2012. Antecedents and consequences of employee engagement: Empirical study of hotel employees and managers. PhD thesis. Kansas University, Manhattan.

Liebowitz, J. 2010. The role of HR in achieving a sustainability culture. Journal of Sustainable Development 3(4): 50-57.

Liu, X. and K. Dong. 2012. Development of the civil servants' performance appraisal system in China: Challenges and improvements. Review of Public Personnel Administration 32(2): 149-168.

Maharaswa, M. M. A. 2013. 'Rebranding the Further Education and Training (FET) sector through leadership and organization development'. Department of Higher Education Briefing. S.A. 24-25 October 2013. 1-21.

Mani, V. and T. Nadu. 2011. Analysis of employee engagement and its predictors. International Journal of Human Resource Studies 1(2): 15-26.

Marshall, C. and B. Rossman. 2011. Designing qualitative research. 5th ed. New Delhi: Sage.

Maslach, C., W. B. Schaufeli and M. P. Leiter. 2001. Job burnout. Annual Review of Psychology 52(1): 397-422. 
Mone, E. M. and M. London. 2010. Employee engagement through effective performance: A practical guide for managers. New York, NY: Routledge.

Mxenge, S. V., M. Dywill and S. Basaza. 2014. Job engagement and employees' intention to quit among administrative personnel at the University of Fort Hare in South Africa. International Journal of Research in Social Sciences September 4(5): 129-144.

National Planning Commission. 2011. Diagnostic overview: Cape Town. Department: The Presidency. 130. http://www.education.gov.za./Link.Click.aspx?Fileticket=FdWq5BIbHkY=Qtabid=889 (accessed 8 October 2015).

Neuman, W. L. 2011. Social research methods: Qualitative and quantitative approaches. 7th ed. Boston, MA: Pearson.

Ngobeni, E. K. and A. Bezuidenhout. 2011. Engaging employees for improved retention at a higher education institution in South Africa. African Journal of Business Management 5(23): 9961-9970.

Ormrod, J. E. and P. D. Leedy. 2010. Practical research, planning and design. 9th ed. Upper Saddle, NJ: Pearson.

Papalexandris, N. and E. Galanaki. 2009. Leadership’s impact on employee engagement: Differences among entrepreneurs and professional CEOs. Leadership and Organisational Development Journal 30(4): 365-385.

Papier, J., S. Needham and T. Mcbride. 2012. Contemporary issues in public FET colleges. Connecting capabilities, individuals and institutions. LMIP Working Paper no. 17.30 March.

Risher, H. 2013. Individual performance goals can be problematic. Compensation \& Benefits Review 45(2): 63-66.

Risher, R. 2012. Employers need to focus on improving performance management. Compensation and Benefits Review 40(4): 189-190.

Rothman, S. and S. Rothman. 2010. Factors associated with employee engagement in South Africa. South African Journal of Industrial Psychology 36(2): 1-12.

Sakovska, M. 2012. Importance of employee engagement in business environment: Measuring the level of administrative personnel in VUC Aarhus and detecting factors requiring improvement. Aarhus University. Aarhus C, Denmark. http://pure.au.dk/portal-asb-student/files/45628761/employeeengagement.pdf (accessed 12 June 2015).

Saks, A. M. 2006. Antecedents and consequences of employee engagement. Journal of Managerial Psychology 21(7): 600-619.

Saks, A. M. and J. A. Gruman. 2011. Getting newcomers engaged: The role of socialization tactics. Journal of Managerial Psychology 26(5): 383-402.

Sanalova, M., S. Llorens, E. Cifre, I. Martinez and W. B. Schaufeli. 2003. Perceived collective efficacy, subjective well-being and task performance among electronic work group: An experienced study. Small Group Research 34: 43-73.

Schaufeli, W. B. and A. B. Bakker. 2004. Job demands, job resources and their relationship with burnout and engagement: A multi-sample study. Journal of Organizational Behavior 25: 293-315.

Schaufeli, W. B., A. B. Bakker and M. Salanova. 2006. The measurement of employee engagement with a brief questionnaire: A cross-national study. Educational and Psychological Measurement 66(4): 701716.

Shuck, B. and K. Wollard. 2010. Employee engagement and human resources development: A seminal review of the literature review of the foundations. Human Resources Development Review 9(1): 89110.

Shuck, B. and T. G. Reio. 2014. Employee engagement and well-being: A moderation model and 
implications for practice. Journal of Leadership and Organisational Studies 2(1): 43-58.

Taipale, S., K. Selander, T. Anttila and J. Natti. 2011. Work engagement in eight European countries: The role of job demands, autonomy, and social support. International Journal of Sociology and Social Policy 31(7/8): 486-504.

Toews, M. L. and A. Yazadjian. 2007. The three-ring circus of academia: How to become the ring master. Innovative Higher Education 32: 113-122. http://dx.doi.org/10.1007/s10755-007-9046-8 (accessed 10 September 2015).

Van Schalkwyk, S., D. H. du Toit, A. S. Bothma and S. Rothmann. 2010. Job insecurity, leadership empowerment behaviour, employee engagement and intention to leave in a petrochemical laboratory. South African Journal of Human Resource Management 8(1): 1-7.

White, P. 2009. Developing research questions: A guide for social scientists. New York, NY: Palgrave Macmillan. 